\title{
A szöveti antitranszglutamináz átmeneti emelkedése coeliakiával nem társult I-es típusú cukorbeteg gyermekekben
}

\author{
Muzslay Eszter dr. ${ }^{1}$ - Hámory Eszter oh. ${ }^{2}$ \\ Herczeg Vivien dr. ${ }^{1}$. Tóth-Heyn Péter dr. ${ }^{1}$ - Körner Anna dr. ${ }^{1}$ \\ Madácsy László dr. ${ }^{1}$ - Luczay Andrea dr. ${ }^{1}$ \\ ${ }^{1}$ Semmelweis Egyetem, Általános Orvostudományi Kar, I. Gyermekgyógyászati Klinika, Budapest \\ ${ }^{2}$ Semmelweis Egyetem, Általános Orvostudományi Kar, Budapest
}

\begin{abstract}
Bevezetés: Az l-es típusú diabetes mellitus és a coeliakia gyakori társulása jól ismert. Néhány tanulmány beszámol átmeneti antitranszglutamináz-emelkedésről l-es típusú diabeteses betegekben, akiknél az emelkedett antitestszint gluténmentes diéta bevezetése nélkül normalizálódik.

Célkitüzés: Kutatásunk során az átmeneti antitranszglutamináz-emelkedés gyakoriságának meghatározását tűztük ki célul. További célunk volt a coeliakia gyakoriságának megállapítása l-es típusú diabetesszel gondozott betegeink között.

Módszer: A Semmelweis Egyetem I. Gyermekgyógyászati Klinikáján 1-es típusú diabetesszel gondozott betegeket vontuk be vizsgálatunkba (238 lány, 265 fiú, medián [IR] életkor az l-es típusú diabetes diagnózisakor: 7,83 [4,6711] év). Vizsgáltuk a jelenség időbeli megjelenését, az emelkedés mértékét, gyakoriságát és az antitest típusát. Leíró statisztikai módszereket és khi-négyzet-próbát alkalmaztunk.

Eredmények: A vizsgált populációban a coeliakia gyakorisága 12,52\%. Átmeneti antitranszglutamináztiter-emelkedést 48 gyermeknél $(10,9 \%)$ észleltünk. Összesen 71 -szer mértünk átmeneti antitranszglutamináz-emelkedést. A gyermekek közül 34 esetben $(70,83 \%)$ egyszer fordult elő emelkedést mutató antitest, a többi betegnél 2-8 alkalommal. Gyakrabban tapasztaltunk izolált IgA-típusú emelkedést, mint izolált IgG-típusút (54 vs. 5).

Következtetés: Az átmeneti antitranszglutamináz-emelkedés gyakorisága magas, összevethető a valódi coeliakiás csoporttal. Kutatásunk alátámasztja a nemzetközi ajánlást, miszerint mérsékelt mértékủ antitranszglutamináz-emelkedés esetén, tünetmentes l-es típusú diabetesszel gondozott betegben a gluténfogyasztás folytatása és az antitestszintek gyakori kontrollja javasolt.
\end{abstract}

Orv Hetil. 2021; 162(48): 1924-1930.

Kulcsszavak: transzglutaminázok, l-es típusú diabetes mellitus, coeliakia, gyermekgyógyászat

\section{Transitional elevation of anti-tissue transglutaminase antibodies in children with} type 1 diabetes mellitus without coeliac disease

\footnotetext{
Introduction: The frequent association of type 1 diabetes mellitus with coeliac disease is well known. Development of transitional elevation of anti-tissue transglutaminase antibodies in the diagnosis of type 1 diabetes is reported in some studies. In these cases, the anti-tissue transglutaminase antibodies returned to normal without gluten-free diet. Objective: Our aim was to assess the frequency of transitional elevation of anti-tissue transglutaminase in our type 1 diabetes patients. We aimed to investigate the prevalence of coeliac disease in patients with type 1 diabetes.

Method: Patients with type 1 diabetes at the Ist Department of Paediatrics, Semmelweis University, were enrolled in the study (238 girls, 265 boys; the median age at the time of type 1 diabetes diagnosis was 7.83 [4.67-11] years). Descriptive statistical analysis was done and the time of appearance, extent, frequency and type of elevated anti-tissue transglutaminase antibodies were examined.

Results: The proportion of children with diagnosed coeliac disease was $12.52 \%$. We detected transitional anti-tissue transglutaminase elevation in 48 cases (10.9\%). Temporarily elevated antibody levels were measured 71 times. In 34 children $(70.83 \%)$, the temporary elevation occured once, while in the others, antibody levels became positive $2-8$ times. The elevation of the IgA antibody was more frequent than the elevation of the IgG antibody (54 vs. 5 ).
} 
Conclusion: The frequency of temporary elevated anti-tissue transglutaminase levels is considered high. Our study confirms the recommendation that in the case of moderate anti-tissue transglutaminase levels with lack of clinical symptoms, control antibody measurement is necessary with ongoing gluten consumption.

Keywords: transglutaminases, diabetes mellitus type 1, coeliac disease, pediatrics

Muzslay E, Hámory E, Herczeg V, Tóth-Heyn P, Körner A, Madácsy L, Luczay A. [Transitional elevation of antitissue transglutaminase antibodies in children with type 1 diabetes mellitus without coeliac disease]. Orv Hetil. 2021; 162(48): 1924-1930.

(Beérkezett: 2021. április 16.; elfogadva: 2021. május 11.)

\begin{abstract}
Rövidítések
anti-tTG $=$ (anti-tissue transglutaminase) szöveti transzglutamináz elleni (antitest); EMA = endomysiumellenes antitest; ESPGHAN $=($ European Society for Paediatric Gastroenterol ogy, Hepatology and Nutrition) Európai Gyermek-gasztroenterológiai, Hepatológiai és Táplálkozástudományi Társaság; HLA = humán leukocytaantigén; ISPAD = (International Society for Pediatric and Adolescent Diabetes) Nemzetközi Gyermek- és Serdülőkori Diabetes Társaság; NOD $=$ (nonobese diabetic) nem elhízott cukorbeteg; T1DM = (type 1 diabetes mellitus) 1-es típusú diabetes mellitus
\end{abstract}

Az 1-es típusú diabetes mellitusra (T1DM) jellemző a hasnyálmirigy béta-sejtjeinek immunmediált vagy idiopathiás pusztulása. Etiológiája heterogén, kialakulásában szerepet játszik a genetikai fogékonyság, és fontosak lehetnek környezeti hatások is [1]. A T1DM-mel élő egyénekben nagyobb a rizikója autoimmun társbetegség kialakulásának nem TIDM-es társaikhoz képest. A betegek majdnem negyedénél diagnosztizálnak egy vagy több autoimmun társbetegséget. Ez a leggyakrabban autoimmun thyreoiditis, melyet szorosan követ a coeliakia, valamint előfordulhatnak még jóval ritkábban: autoimmun adrenalitis, autoimmun gastritis, autoimmun hepatitis, juvenilis idiopathiás arthritis, Sjögren-szindróma, szisztémás lupus erythematosus, scleroderma, vitiligo, alopecia, sarcoidosis, psoriasis, polyglandularis autoimmun szindróma, Crohn-betegség vagy colitis ulcerosa. A T1DM-mel élő gyermekek körében a coeliakia prevalenciája magasabb, mint az átlagpopulációban: 1\% és 10\% között változik, a prevalencia nemzetközi szinten 3,5\% [2]. Az adatok között észlelt eltérést a különböző diagnosztikus és szürőmódszerek magyarázhatják [3]. A két betegség együttes előfordulásának alapja a genetikai prediszpozíció (magas kockázatú HLA-gének jelenléte: HLA-DQ2, HLA-DQ8) [4]. Ezen túlmenően több elmélet is magyarázhatja a két betegség közötti kapcsolatot, így együttes előfordulásuk magasabb gyakoriságát. Az egyik elmélet szerint T1DM-ben az immunrendszer diszfunkciója generalizálódhat, és kiterjedhet a kóros immunválasz más szövetek és a gliadin felé is a genetikailag hajlamos egyénekben. Egy másik elmélet szerint a coeliakia kialakulása a stimulált immunrendszerrel áll össze- függésben, a polyclonalis B-sejt-aktiváció vezethet autoimmun társbetegségek kialakulásához [5].

A TIDM gyakori coeliakiával való együttes előfordulása miatt ajánlott a TIDM-betegek szûrése coeliakia irányában [6]. Az ISPAD (International Society for Pediatric and Adolescent Diabetes) jelenlegi ajánlása szerint ez történjen meg a T1DM diagnózisakor, valamint 2 és 5 év elteltével. Tünetek vagy elsőfokú rokon coeliakiaérintettsége esetén gyakrabban [2]. A T1DM-mel élő betegek a coeliakia diagnózisa esetén a gluténmentes diéta megfelelő betartásakor kihívásokkal néznek szembe. A gluténmentes diéta betartását segítheti a dietetikus elérhetősége, a rendszeres követés, valamint a diéta okának és céljának jobb megértése (az edukáció szerepe). A gluténmentes diéta be nem tartása negatívan befolyásolhatja az életminőséget és a metabolikus kontrollt is [7]. A gluténmentes diéta általi korlátozások a TIDM-ben tartandó étrenddel együtt jelentős terhet jelentenek a betegek és családjuk számára. Ezen gyermekek az étrend betartásakor több nehézséggel szembesülnek, mint azon társaik, akiknél vagy T1DM, vagy coeliakia áll fenn. A T1DM és a coeliakia együttes fennállása esetén a nem megfelelő terápiás kontroll az anyagcsere romlásához, a diabetes szövődményeinek progressziójához és növekedési elmaradáshoz vezethet. Ezen gyermekekre és étrendjük tartására kiemelt figyelmet kell fordítani, ugyanis mind a két betegség jelenlegi hatékony kezelési módja az élethoszszig tartó korlátozó diéta betartása [8].

Az ESPGHAN (European Society for Paediatric Gastroenterology, Hepatology and Nutrition) jelenlegi ajánlása szerint T1DM-beteg (tehát rizikócsoportba tartozó beteg) esetén a coeliakia diagnózisa kimondható, ha a mért anti-tTG-IgA-titer eléri vagy meghaladja a referenciatartomány felső határának tízszeresét, és ezzel együttesen az EMA-IgA-antitest pozitív. Ez az ún. szerológiaalapú megközelítés, vagy „no biopsy approach”. Abban az esetben, ha az anti-tTG-IgA szintje nem emelkedett, és a teljes-IgA-szint normális, ki kell zárni az álnegativitás lehetőségét. Az álnegatív eredmény hátterében gluténmentes diéta, immunszuppresszáns-terápia állhat. Ha ezek egyike sem áll fenn, akkor a coeliakia diagnózisa kizárható. Gluténmentes diétát tartó vagy immunszuppresszív kezelés alatt álló beteg esetén javasolt a $H L A$-gé- 
nek vizsgálata: a $H L A-D Q 2 / 8$ negativitása esetén a coeliakia nem valószínú, pozitivitása esetén megfontolandó az endoszkópos mintavétel. Amennyiben alacsony teljesIgA-szintet találunk, javasolt az IgG-típusú antitestek mérése. Ha az anti-tTG-IgG, EMA-IgG vagy antideamidáltgliadin-IgG negatív, és nem áll fenn az álnegativitás lehetősége, a coeliakia diagnózisa kizárható. Szövettani mintavétel az alábbi esetekben indokolt: az anti-tTGIgA-emelkedés eléri a tízszeres szintet, azonban az EMA-IgA-szerológia negatív, illetve ha alacsony összIgA-szint mellett az anti-tTG-IgG és/vagy az EMA-IgG és/vagy az antideamidáltgliadin-IgG pozitív vagy emelkedett. Biopszia esetén a látható eltérések minőségét és mennyiségét a Marsh-klasszifikációval jellemezzük (Marsh 0-3.). A coeliakia diagnózisa felállítható, amenynyiben a minta a Marsh-beosztás szerinti 2. vagy 3. stádiumú [9]. A diagnosztikus protokollt T1DM-es - mint rizikócsoportba tartozó - betegre vonatkoztatva az 1 . ábrán mutatjuk be.

Irodalmi adatok támasztják alá, hogy coeliakiabetegség kialakulása nélkül is észlelhető anti-tTG-emelkedés TIDM-betegekben. A jelenség a diabetes diagnózisakor vagy a későbbi követés során jelenhet meg, és gluténmentes diéta nélkül normalizálódik [10-13].

$\mathrm{Az}$ átmeneti antitest-emelkedés jelentősége, hogy ezen gyerekeket nem tartjuk coeliakiásnak. A jelenség pontos oka nem ismert. NOD- (nonobese diabetic) ege- rekben megfigyelték az intestinalis anti-tTG-antitestek jelenlétét, ami szérum-anti-tTG-antitest-pozitivitással társult. Ezekben az egerekben a jelenség az étrend gluténtartalmával nem állt összefüggésben. Felmerül, hogy ez vonatkozik azon T1DM-betegekre is, akiknél átmeneti anti-tTG-antitest-emelkedés észlelhető [14]. A NOD-egerekben megfigyelt anti-tTG-válaszhoz [15] hasonlóan T1DM-betegekben a T1DM-hez vezetó autoimmun folyamat állhat az átmeneti anti-tTG-szeropozitivitás hátterében [14].

T1DM-gyermekek átmeneti anti-tTG-emelkedése esetén, amennyiben az emelkedés mértéke nem haladja meg a felső határ tízszeresét, és a coeliakia diagnózisa nem állítható fel, a gluténmentes diéta azonnali bevezetése helyett a gluténtartalmú étrend folytatandó, az antitestszintek gyakori kontrollja mellett $(3,6$, és 12 hónap múlva). Ezzel elkerülhetjük a nem szükséges beavatkozások elvégzését, az esetleges téves diagnózis felállítását, valamint csökkenthetjük a gyermekek és családok további pszichológiai terhét [11].

\section{Módszerek}

Vizsgálatunk során az I. Gyermekgyógyászati Klinikán TlDM-mel gondozott gyermekek adatait gyưjtöttük össze. Retrospektív kutatásunkba azokat a betegeket vontuk be, akikról a diagnózis kezdetétől fogva rendel-

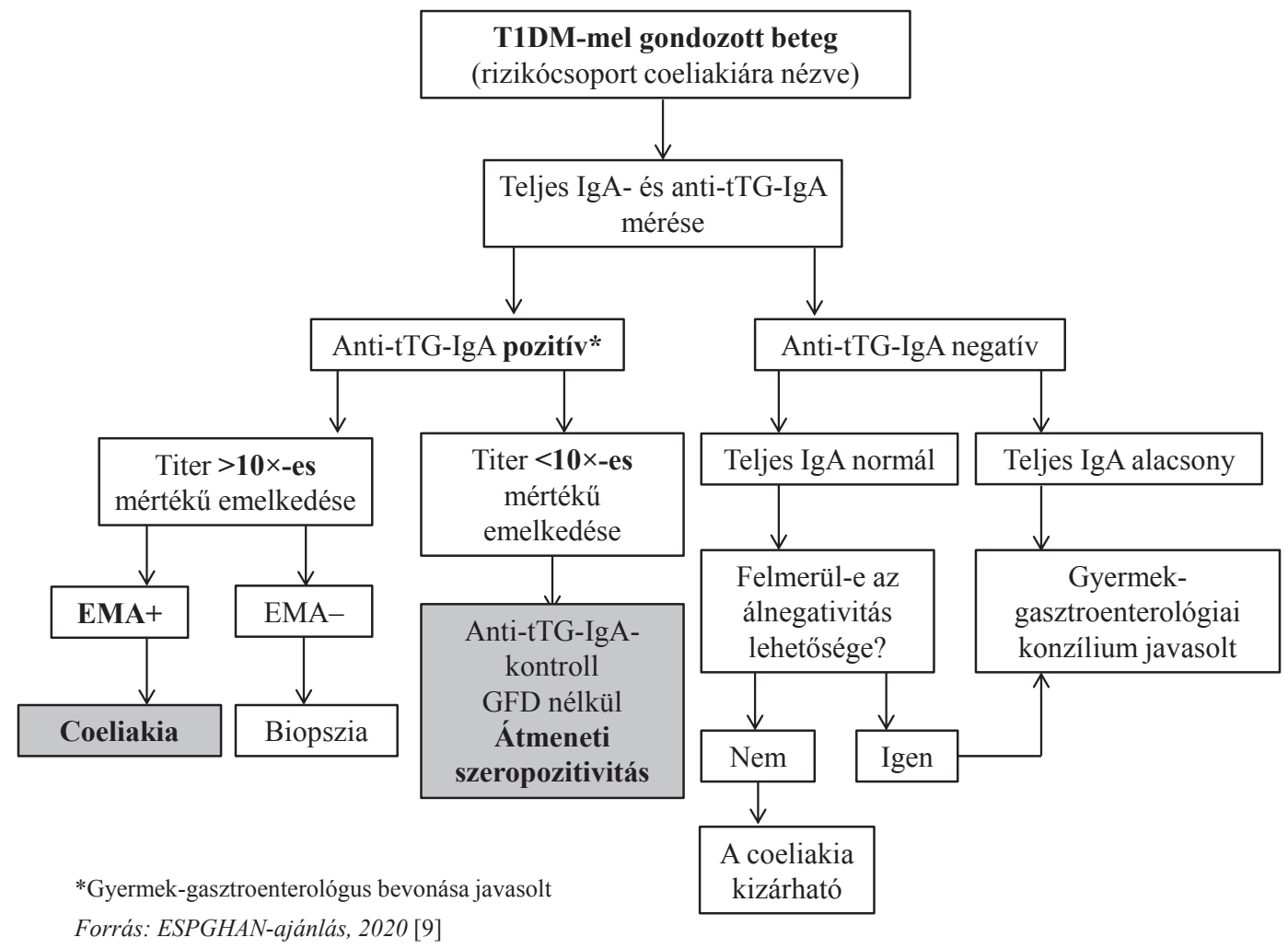

1. ábra $\quad$ A coeliakia diagnosztikus protokollja l-es típusú diabeteses betegre vonatkozóan

anti-tTG = szöveti transzglutamináz elleni (antitest); EMA = endomysiumellenes antitest; ESPGHAN = Európai Gyermek-gasztroenterológiai, Hepatológiai és Táplálkozástudományi Társaság; GFD = gluténmentes diéta; IgA = immunglobulin-A; T1DM = l-es típusú diabetes mellitus 
1. táblázat |A vizsgált populáció megoszlása nemek szerint

\begin{tabular}{l|c|c|c|c|c|c}
\hline & \multicolumn{2}{|c|}{ Coeliakia } & \multicolumn{2}{c|}{$\begin{array}{c}\text { Átmeneti } \\
\text { szeropozitivitás }\end{array}$} & \multicolumn{2}{c}{ Csak T1DM } \\
\hline Nem & Fiú & Lány & Fiú & Lány & Fiú & Lány \\
\hline Esetszám & 25 & 38 & 20 & 28 & 220 & 172 \\
$\begin{array}{l}\text { Százalékos } \\
\text { megoszlás }\end{array}$ & $39,7 \%$ & $60,3 \%$ & $41,7 \%$ & $58,3 \%$ & $56,1 \%$ & $43,9 \%$ \\
\hline
\end{tabular}

T1DM = 1-es típusú diabetes mellitus

kezésre álltak a vizsgált adatok, így kutatásunkba 503 beteg került. Regisztráltuk a TIDM diagnózisakor és a későbbi követés során mért anti-tTG-IgA- és-IgG-antitest-szinteket, valamint coeliakiásnak minősített betegeinkben a fentieken kívül még az EMA-meghatározás, továbbá a biopszia eredménye (amennyiben rendelkezésre állt) került rögzítésre. Az antitestszinteket a normáltartomány felső határához viszonyítottuk, így relatív értékekkel dolgoztunk (a mért érték hányszorosa a határértéknek). Retrospektív vizsgálatunk három fó csoportja: 1) a követés során átmeneti antitest-emelkedést nem mutató, coeliakiával nem diagnosztizált gyermekek (a továbbiakban: csak T1DM-es csoport); 2) coeliakiával diagnosztizált gyermekek, akiknél gluténmentes diéta tartása indokolt; valamint 3) a követés során átmeneti antitest-emelkedést mutató gyermekek. Ezen utóbbi csoportba azok tartoznak, akiknél a T1DM diagnózisakor vagy a későbbi követés során átmeneti anti-tTGantitest-emelkedést tapasztaltunk.

Kutatásunkban mind kategorikus, mind numerikus változókat vizsgáltunk. A statisztikai értékeléshez khinégyzet- és Shapiro-Wilk-próbát alkalmaztunk, a szignifikanciaszintet egységesen 0,05-nek tekintettük.

\section{Eredmények}

A betegcsoportot alkotó 503 gyermek között a fiú-lány arány: 52,7/47,3\% (265/238 fó). Köztük a TlDM diagnózisának életkori mediánja 7,83 (4,67-11,0) év. A vizsgált 503 T1DM-es gyermek közül 63-at tartunk coeliakiásnak, és 48 esetben észleltünk átmeneti antitestemelkedést (1. táblázat).

A coeliakia előfordulása T1DM-betegeink körében 63 esetben volt megfigyelhető, ez 12,52\%-os prevalenciának felel meg. Összehasonlítva a coeliakiával diagnosztizált és a csak T1DM-mel élő gyermekek nemi megoszlását, azt tapasztaltuk, hogy a coeliakiás csoportba szignifikánsan több lány tartozik, mint a csak T1DM-es csoportba $(\mathrm{p}=0,01512)$.

\section{A coeliakia diagnosztikájának retrospektí vizsgálata}

A coeliakiás csoportban megvizsgáltuk, hogy min alapult a diagnózis felállítása. 6 páciensnél a coeliakia diagnózisa a T1DM elött született. Mivel betegeinket a TIDM manifesztációjától követtük, az ő esetükben nem állt rendelkezésünkre elegendő adat a coeliakia diagnózisának idejéből, így a vizsgálat ezen részébe óket nem vettük be. Így a coeliakia diagnosztikájának vizsgálata során 57 gyermek adatait elemeztük (2. ábra).

Az 57 gyermekből 48-nál haladta meg az anti-tTGantitest szintje a tízszeres határértéket a coeliakia diagnózisakor. Közülük 7 gyermeknél történt szövettani mintavétel, amelynek besorolása minden esetben Marsh 2 -esnek vagy 3 -asnak bizonyult. Azon gyermekek között, akiknél szövettani mintavétel nem történt, az EMA

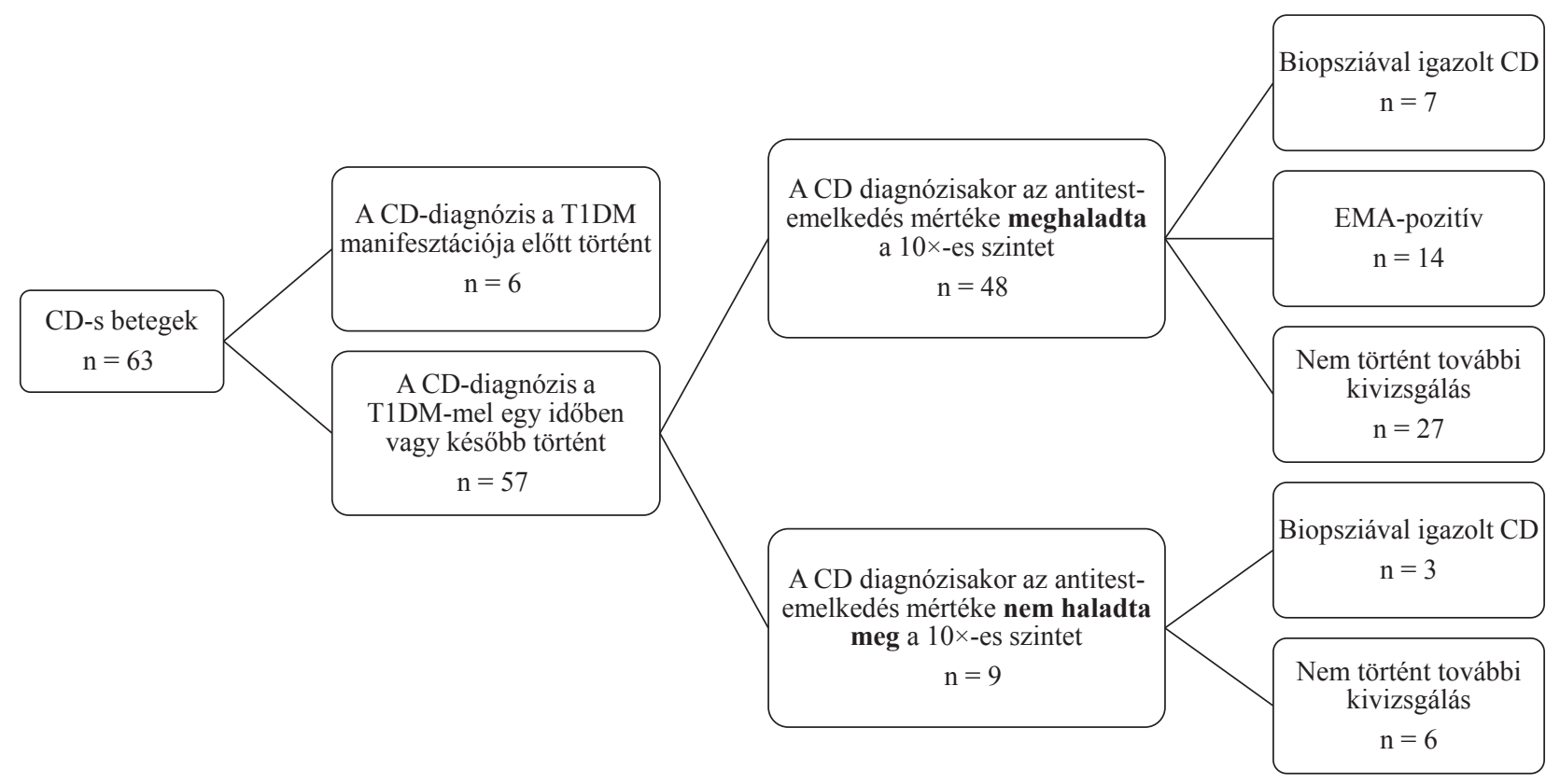

2. ábra $\quad$ A coeliakia diagnosztikája során elvégzett vizsgálatok a jelenleg coeliakiásnak tartott gyermekek körében $\mathrm{CD}=$ coeliakiabetegség; EMA = endomysiumellenes antitest; T1DM = l-es típusú diabetes mellitus 
meghatározása során 14 esetben találtak pozitivitást. A többi 27 gyermek esetén további vizsgálat nem történt coeliakia irányában.

Az 57-ből 9 gyermeknél az anti-tTG-antitest-emelkedés mértéke nem haladta meg az ajánlások szerinti értéket, a felső határ tízszeresét, a coeliakiadiagnózis kimondásakor. Ebből a 9 gyermekből 3-nál történt szövettani mintavétel, amelynek besorolása mindhármuk esetén Marsh 2-esnek bizonyult, tehát igazolta a coeliakia diagnózisát. A többi 6 gyermek esetén az ESPGHAN 2020. évi ajánlása [9] szerinti coeliakia-kritériumrendszer nem teljesült, mivel e szerint az ajánlás szerint, ha az antitestemelkedés mértéke nem éri el a minimum tízszeres szintet, biopszia elvégzése javasolt a coeliakia diagnózisának megállapításához az álpozitív esetek számának csökkentésére.

Összességében a coeliakiásnak tartott betegek közül 10 esetben történt biopsziás mintavétel, amelyek kivétel nélkül igazolták a coeliakia diagnózisát. A magasan emelkedett antitesttiterrel bíró csoportban 14 esetben igazolódott EMA-pozitivitás, amely az ő esetükben megerősíti a coeliakia diagnózisát. Így az 57-ből 24 gyermeknél teljesül a jelenlegi ajánlás alapján a coeliakia diagnózisa. A többi 33 beteg esetén a jelenlegi ajánlás alapján nem egyértelmû a diagnózis. Az ő esetükben a kórlefolyás figyelembevételével felmerülhet a diagnózis revíziójának szükségessége.

\section{Az átmeneti antitest-emelkedés elófordulása}

A 440, nem coeliakiás beteg közül 48 gyermeknél regisztráltunk átmeneti antitest-emelkedést, így annak elöfordulása 10,9\% volt. A nemi megoszlás nem bizonyult szignifikánsan különbözőnek az átmeneti szeropozitivitással bírók és a csak T1DM-es csoport között ( $\mathrm{p}=$ $0,5763)$.

A 48 gyermekból 29-nél $(60,4 \%)$ a T1DM diagnózisakor már észlelhető volt emelkedett anti-tTG-érték, további 6 gyermeknél $(12,5 \%)$ az első emelkedett antitTG-értéket az 1 éves kontrollvizsgálat során (tehát 1 éves betegségfennállás után) mértük. 13 gyermeknél $(27,1 \%)$ az első emelkedett anti-tTG-szintet a 2 éves kontroll során vagy később mértük. 8 éves vagy hoszszabb betegségtartam után már egy esetben sem észleltünk emelkedett antitestértéket.

Az összes mért emelkedés közül 54 esetben izolált anti-tTG-IgA-, 5 esetben izolált anti-tTG-IgG-, valamint további 6 esetben együttes anti-tTG-IgA- és -IgG-emelkedést észleltünk. Az együttes emelkedést mutató 6 esetben összesen 12-szer mértünk emelkedett anti-tTG IgA és IgG szintet. (2. táblázat). Az átmeneti anti-tTGemelkedés időbeli lefolyását tekintve megkülönböztettük az egyszeri és a többszöri antitest-emelkedést. A többszöri emelkedés típusa lehet perzisztáló vagy fluktuáló emelkedés. Perzisztáló emelkedés esetén többször volt észlelhető a jelenség egymás utáni kontrollok során; a fluktuáló emelkedés során a többszöri emelkedések kö-
2. táblázat $\mid$ Az anti-tTG-antitestek gyakoriságának megoszlása az átmeneti anti-tTG-szeropozitivitást mutató csoportban

\begin{tabular}{lcccc}
\hline & $\begin{array}{c}\text { Anti- } \\
\text { tTG-IgA }\end{array}$ & $\begin{array}{c}\text { Anti- } \\
\text { tTG-IgG }\end{array}$ & $\begin{array}{c}\text { Anti-tTG- } \\
\text { IgA és -IgG } \\
\text { együttes } \\
\text { emelkedése }\end{array}$ & Összesen \\
\hline $\begin{array}{l}\text { A T1DM } \\
\text { diagnózisakor }\end{array}$ & 23 & 3 & 3 & 32 \\
$\begin{array}{l}\text { A késóbbi } \\
\text { követés során }\end{array}$ & 31 & 2 & 3 & 39 \\
\hline Összesen & 54 & 5 & 12 & 71 \\
\hline
\end{tabular}

anti-tTG = szöveti transzglutamináz elleni (antitest); IgA = immunglobulin-A; IgG = immunglobulin-G; T1DM = 1-es típusú diabetes mellitus

zött normálantitestszintek is mérhetők voltak. Egyszeri emelkedést 34 gyermeknél, perzisztáló emelkedést 9 gyermeknél, fluktuáló emelkedést 5 gyermeknél észleltünk. A legtöbb esetben (71\%) egyszeri emelkedést tapasztaltunk. Az összes anti-tTG-emelkedést mutató eset, összesen 111 fó között a spontán ( 1 éven belüli) normalizáció aránya betegcsoportunkban 30,6\%-nak bizonyult.

A legkisebb mértékü emelkedés 1,05-szor, a legnagyobb 10,3-szer haladta meg a normáltartomány felső határát. Az emelkedés mértéke ebben az egy esetben haladta meg a tízszeres határértéket. Az emelkedés mértékének mediánja a normálérték felső határának 1,5-szerese, tehát mérsékelt mértékű.

\section{Életkori megoszlás}

Az átmeneti emelkedést mutató csoportban a gyermekek átlagéletkora a T1DM diagnózisakor $6,75( \pm 3,73)$ év, a coeliakiás csoportban a medián érték 6,41 (2,4l-10,41) év, míg a csak T1DM-es csoportban a medián érték 8,29 (4,31-12,27) év. Két életkori csoportot határoztunk meg a T1DM diagnózisának felállítása alapján. Az egyik csoportba azok kerültek, akik a 10. életévüket nem töltötték be a TIDM diagnózisakor, míg a másik csoportba azok, akik betöltötték. Azt találtuk, hogy a coeliakiás csoportban nincs szignifikáns különbség a T1DM diagnózisakori életkort tekintve a csak T1DM-es csoporthoz képest $(\mathrm{p}=0,1761)$. Ugyanezen életkori csoportokra osztva az átmeneti antitest-emelkedést mutató gyermekeket, azt találtuk, hogy náluk a T1DM diagnózisa szignifikánsan fiatalabb életkorban született, mint a csak T1DM-es csoportban $(\mathrm{p}=0,0401)$.

\section{Megbeszélés}

Kutatásunk során a coeliakiára jellemző antitestek átmeneti emelkedését és a coeliakia diagnosztikáját értékeltük a Semmelweis Egyetem I. Gyermekgyógyászati Klinikáján gondozott T1DM-es populációban. Vizsgálatunk során a coeliakia előfordulása $12,52 \%$-nak bizonyult, ami a nemzetközi irodalmi adatokkal összevetve magasnak 
tekinthető. Egy korábbi felmérés a gyakoriságot 8,3\%nak találta a T1DM-es populációban, ami lényegesen magasabb volt a környező országokban tapasztaltnál. E tanulmányban az akkor érvényes ESPGHAN-ajánlás alapján a coeliakia diagnózisa a biopsziára épült, boholyatrophia jelenléte esetén mondták ki a coeliakia diagnózisát [16].

Vizsgálatunk során áttekintettük, hogy min alapul a coeliakia diagnózisa populációnkban. A coeliakiásnak tartott gyermekek között 24 esetben találtunk az ESPGHAN 2020. évi nemzetközi ajánlása szerint igazolt coeliakiadiagnózist. A további 33, coeliakiásnak tartott gyermek esetén nem teljesül az említett kritériumrendszer. A kivizsgálás során a szülő sok esetben nem egyezett bele az endoszkópos mintavételbe, így ezen gyermekek esetén a korábbi algoritmusban diagnosztikus kritériumként szereplő szövettani lelet hiányában történt meg a coeliakia diagnózisának kimondása és a gluténmentes diéta bevezetése. Így esetükben felmerül, hogy a diagnózis a kórlefolyás és a laboratóriumi értékek ismeretében esetleg újragondolandó lehet. A tapasztalt magas coeliakiaprevalencia hátterében a tévesen coeliakiásnak diagnosztizált átmeneti szeropozitív esetek állhatnak. Emellett szeretnénk megemlíteni, hogy az összehasonlítási alapul vett országokhoz képest az általunk vizsgált populációban kevesebb esetben történt mintavétel, ami szintén hozzájárulhat az összehasonlítási alapul vett alacsonyabb prevalenciához.

Vizsgáltuk továbbá az átmeneti anti-tTG-antitestemelkedés gyakoriságát, amely a nem coeliakiás populációban 10,9\%-nak bizonyult. Eredményünket összehasonlítottuk a nemzetközi irodalommal, ezt a 3. táblázatban mutatjuk be [10-13]. Az idézett kutatások a spontán ( 1 éven belüli) anti-tTG-normalizáció arányát vizsgálták a T1DM-betegcsoportban, azaz hogy az öszszes anti-tTG-emelkedést mutató beteg között milyen arányban volt mérhető normális anti-tTG-szint az első észlelést követő 1 éven belül. Elmondhatjuk, hogy eredményeink korrelálnak a bemutatott nemzetközi irodalmi adatokkal.

Kutatásunkban kitértünk az átmenetileg emelkedett anti-tTG-antitestek típusára ( $\operatorname{IgA}$ vagy $\operatorname{IgG}$ ) is: az $\operatorname{IgA-}$ típusú anti-tTG-antitest gyakrabban mutatott emel-

3. táblázat |Az emelkedést mutató anti-tTG-antitest spontán (1 éven belüli) normalizációjának aránya a T1DM-betegcsoportban [10-13]

\begin{tabular}{lc}
\hline Forrás & A spontán normalizáció aránya \\
\hline Waisbourd-Zinman, et al. [12] & $35,4 \%$ \\
Castellaneta, et al. [11] & $27,7 \%$ \\
Rinawi, et al. [10] & $38,2 \%$ \\
Unal, et al. [13] & $23,3 \%$ \\
Az általunk vizsgált populáció & $30,6 \%$ \\
\hline
\end{tabular}

anti-tTG = szöveti transzglutamináz elleni (antitest); T1DM = 1-es típusú diabetes mellitus kedést, mint az IgG-típusú. A gyakoribb IgA-típusú anti-tTG-titer-emelkedés magyarázatára jelenleg nincs irodalmi adat. Az izolált IgG-típusú anti-tTG-emelkedésnek szelektív IgA-hiányban van jelentősége.

Vizsgáltuk továbbá ugyanezen csoportokban a TIDM diagnózisakor az életkort, illetve ennek különbözőségét az egyes csoportok között. A coeliakiás csoportban nem találtunk szignifikáns különbséget a TIDM diagnózisának életkori megoszlásában. Átmeneti szeropozitivitással rendelkező betegeink körében azonban a T1DM diagnózisa fiatalabb életkorban született, mint a csak T1DMes betegcsoportban.

A bemutatott nemzetközi ajánlás [9] szerint, ha az antitest-emelkedés mértéke nem éri el a tízszeres határértéket, akkor a diagnózis kimondásához mindenképpen biopszia elvégzése javasolt. Mivel a T1DM-betegek esetén megfigyelt átmeneti szeropozitivitás jelensége ismert, eltekinthetünk a szövettani mintavételtől tünetmentes, mérsékelt emelkedéssel bíró beteg esetén. Szeretnénk továbbá hangsúlyozni, hogy a coeliakiaspecifikus antitest pozitivitása esetén a coeliakia diagnózisa csak a nemzetközi ajánlásokban bemutatott algoritmus alapján hozható meg. Így elkerülhető az átmeneti szeropozitivitással bíró gyermek tévesen coeliakiásnak minősítése.

\section{Következtetés}

Összefoglalva elmondhatjuk, hogy a nem coeliakiás T1DM-populáció 10,9\%-a mutatott átmeneti anti-tTGemelkedést. A jelenség gyakorisága figyelemfelkeltő és nem elhanyagolható mértékú. Eredményeink jelentik az első hazai felmérést a T1DM-betegek átmeneti antitTG-titer-emelkedésére vonatkozóan. Az általunk észlelt coeliakiaprevalencia a nemzetközi irodalommal összehasonlítva magasnak tekinthető. E két következtetés alapján felmerül a gondozott T1DM-es és coeliakiás betegek coeliakiadiagnózis-revíziójának szükségessége a legújabb ajánlás szerint. Előfordulhat, hogy a jelenleg coeliakiásnak tartott betegek közül valakinél átmeneti emelkedés fordult elő, így a coeliakia diagnosztikus újragondolását követően az átmeneti antitest-emelkedés előfordulásának növekedése várható. Fontosnak tartjuk hangsúlyozni a coeliakia megfelelő és pontos diagnosztikáját, mivel mind a nem megalapozott diagnózisnak, mind a fel nem ismert eseteknek megvannak a veszélyei. Nem megalapozott diagnózis esetén a kétféle szigorú diéta kedvezőtlenül hat az életminőségre és a lelki fejlődésre, pszichés teher a családra nézve, ezen túl a gluténmentes diéta anyagi vonzata jelentős. Az időben fel nem ismert esetek az anyagcsere romlásához, a szövődmények progressziójához és hiányállapotokhoz vezethetnek.

Anyagi támogatás: A kézirat megírása anyagi támogatásban nem részesült. 
Szerzôi munkamegosztás: M. E.: Irodalomkutatás, adatgyưjtés, a cikk elkészítése. H. E.: Adatgyűjtés. H. V.: Adatgyưjjtés, szakmai támogatás, a kézirat korrekciója. T.-H. P.: A vizsgált betegek diabetológiai gondozása, szakmai segítségnyújtás, a kézirat korrekciója. K. A., M. L.: A vizsgált betegek diabetológiai gondozása. L. A.: A vizsgált betegek diabetológiai gondozása, szakmai segítségnyújtás, folyamatos segítség a kézirat megírásában, a kézirat korrekciója. A cikk végleges változatát mindegyik szerző elolvasta és jóváhagyta.

Érdekeltségek: A szerzőknek nincsenek érdekeltségeik.

\section{Irodalom}

[1] Mayer-Davis EJ, Kahkoska AR, Jefferies C, et al. ISPAD Clinical Practice Consensus Guidelines 2018: definition, epidemiology, and classification of diabetes in children and adolescents. Pediatr Diabetes 2018; 19(Suppl 27): 7-19.

[2] Mahmud FH, Elbarbary NS, Fröhlich-Reiterer E, et al. ISPAD Clinical Practice Consensus Guidelines 2018: other complications and associated conditions in children and adolescents with type 1 diabetes. Pediatr Diabetes 2018; 19(Suppl 27): 275-286.

[3] Körner A. Other diseases associated with childhood and adolescent diabetes. In: Barkai L, Madácsy L. (eds.) Handbook of pediatric diabetes. [A gyermek- és serdülőkori diabeteshez társuló egyéb betegségek. In: Barkai L, Madácsy L. (szerk.) A gyermekdiabetológia kézikönyve.] SpringMed Kiadó, Budapest, 2019; pp. 215-223. [Hungarian]

[4] Deja G, Sikora D, Pyziak-Skupien A, et al. The usefulness of genotyping of celiac disease-specific HLA among children with type 1 diabetes in various clinical situations. J Diabetes Res. 2020; 2020: 7869350

[5] Kakleas K, Soldatou A, Karachaliou F, et al. Associated autoimmune diseases in children and adolescents with type 1 diabetes mellitus (TIDM). Autoimmun Rev. 2015; 14: 781-797.

[6] Sinkó E, Derzbach L, Körner A, et al. Co-occurrence of celiac disease and type 1 diabetes mellitus. [A coeliakia és az l-es típusú diabetes mellitus együttes előfordulása.] Gyermekgyógyászat 2015; 66: 359-362. [Hungarian]
[7] Smart CE, Annan F, Higgins LA, et al. ISPAD Clinical Practice Consensus Guidelines 2018: nutritional management in children and adolescents with diabetes. Pediatr Diabetes 2018; 19 (Suppl 27): 136-154.

[8] Saadah OI, Zacharin M, O'Callaghan A, et al. Effect of glutenfree diet and adherence on growth and diabetic control in diabetics with coeliac disease. Arch Dis Child. 2004; 89: 871-876.

[9] Husby S, Koletzko S, Korponay-Szabó I, et al. European Society Paediatric Gastroenterology, Hepatology, and Nutrition guidelines for diagnosing coeliac disease 2020. J Pediatr Gastroenterol Nutr. 2020; 70: 141-156.

[10] Rinawi F, Badarneh B, Tanous O, et al. Elevated anti-tissue transglutaminase-antibodies in children newly diagnosed with type 1 diabetes do not always indicate coeliac disease. Acta Paediatr. 2019; 108: 149-153.

[11] Castellaneta S, Piccinno E, Oliva M, et al. High rate of spontaneous normalization of celiac serology in a cohort of 446 children with type 1 diabetes: a prospective study. Diabetes Care 2015; 38: 760-766.

[12] Waisbourd-Zinman O, Hojsak I, Rosenbach Y, et al. Spontaneous normalization of anti-tissue transglutaminase antibody levels is common in children with type 1 diabetes mellitus. Dig Dis Sci. 2012; 57: 1314-1320.

[13] Unal E, Demiral M, Baysal B, et al. Frequency of celiac disease and spontaneous normalization rate of celiac serology in children and adolescent patients with type 1 diabetes. J Clin Res Pediatr Endocrinol. 2021; 13: 72-79.

[14] Maglio M, Florian F, Vecchiet M, et al. Majority of children with type 1 diabetes produce and deposit anti-tissue transglutaminase antibodies in the small intestine. Diabetes $2009 ; 58$ : 1578-1584.

[15] Sblattero D, Maurano F, Mazzarella G, et al. Characterization of the anti-tissue transglutaminase antibody response in nonobese diabetic mice. J Immunol. 2005; 174: 5830-5836.

[16] Arató A, Körner A, Veres G, et al. Frequency of coeliac disease in Hungarian children with type 1 diabetes mellitus. Eur J Pediatr. 2003; 162: 1-5.

(Luczay Andrea dr., Budapest, Bókay J. u. 53.,1083 e-mail: luczay.andrea@med.semmelweis-univ.hu)

\section{"Etiam capillus unus habet umbram suam." (Egyetlen hajszálnak is megvan a maga árnyéka.)}

A cikk a Creative Commons Attribution 4.0 International License (https://creativecommons.org/licenses/by/4.0/) feltételei szerint publikált Open Access közlemény, melynek szellemében a cikk bármilyen médiumban szabadon felhasználható, megosztható és újraközölhetö, feltéve, hogy az eredeti szerző és a közlés helye, illetve a CC License linkje és az esetlegesen végrehajtott módosítások feltüntetésre kerülnek. (SID_1) 